\title{
63- Analysis of everyday life and everyday resistance of the housewives in Rachel Cusk's Arlington Park (2006)'
}

Gözde HAN²

Nalan TURNA3

APA: Han, G.; Turna, N. (2021). Analysis of everyday life and everyday resistance of the housewives in Rachel Cusk's Arlington Park (2006). RumeliDE Dil ve Edebiyat Araştırmaları Dergisi, (25), 1045-1054. DOI: 10.29000/rumelide.1036610.

\begin{abstract}
Sociologists of everyday life have regenerated the notion of everyday with creative potential, especially after the 1970s. The ability to make the familiar unfamiliar has posited everyday life studies with multifaceted realities which can embrace the human situation of emancipation and oppression. The mundane reality of everyday life practices is freighted with power and resistance. Therefore, everyday life practices have to be scrutinized as they have become a site upon which agency is situated. In this sense, the sphere of everyday life can be regarded as a space of exploitation and liberation at the same time. The power relations in everyday life practices conceptualize the notion in a contested manner; thus, resistance. The present paper will analyze the everyday life practices of housewives in the suburb of London to discover the resistance and the possibility of emancipation narrated in the novel Arlington Park (2006) written by Rachel Cusk. The analysis here is based on Henri Lefebvre's theorization of the notion in a dialectical manner, suggesting that it can be both oppressive and liberative. Discovering the potential everyday holds for the housewives accentuates the value of domestic labor in transforming the female actors. In this sense, Michel de Certeau's celebration of everyday as a sphere of resistance will be taken into account in analyzing the resistant activities of the housewives in the abovementioned novel. This paper proposes the possibility of emancipation for the housewives who carry out their everyday practices by situating the notion of everyday as a mediator space.
\end{abstract}

Keywords: Everyday life, housewives, Arlington Park, domestic labor

\section{Rachel Cusk'ın Arlington Park (2006) isimli romanında ev kadınlarının gündelik hayatının ve direnişinin analizi4}

$\ddot{O} \mathbf{z}$

Gündelik hayat kavramı, özellikle 1970'lerden sonra yaratıcı bir potansiyel ve dinamizm ile gündelik hayat çalışmaları yapan sosyologlar tarafından yeniden canlandırılmıştır. Bu kavram, bilinen olanı bilinmez kılabilme özelliği ile gündelik hayat çalışmalarını baskı ve özgürleşme gibi insan hallerini kucaklayan, çok yüzlü gerçekliklerle donatmıştır. Gündelik hayat pratiklerinin bilinen ve olağan gerçekliği güç, fırsat ve başkaldırı gibi kavramları da içinde barındırır. Tüm bu nedenlerle gündelik

This paper was prepared by benefiting from the first author's doctoral thesis.

Öğr. Gör., Boğaziçi Üniversitesi, Yabancı Diller Yüksekokulu, İleri İngilizce Bölümü (İstanbul, Türkiye), gozde.han@boun.edu.tr, ORCID ID: 0ooo-0002-8437-7395 [Araştırma makalesi, Makale kayıt tarihi: 02.09.2021-kabul tarihi: 20.12.2021; DOI: 10.2900o/rumelide.1036610]

Doç. Dr., Ylldız Teknik Üniversitesi, Fen-Edebiyat Fakültesi, İnsan ve Toplum Bilimleri (İstanbul, Türkiye), nturna@yildiz.edu.tr, ORCID ID: 00oo-00o1-7511-609X

Bu çalışma birinci yazarın doktora tezinden üretilmiştir. 
hayat pratikleri kültür, kimlik, sosyal ilişki ve öznellik gibi kavramların yerleștirildiği bir alan olarak itina ile incelenmelidir. Bir başka husus ise gündelik hayat alanın, özgürlük ve baskı alanı olarak görülebilmesidir. Gündelik hayat pratikleri içerisinde gerçekleşen güç ilişkileri, gündelik hayat kavramını, tartışmaya açık bir şekilde ele almaktadır ve bir direniş biçimine yol açmaktadır. Bu çalışma da Rachel Cusk'ın Arlington Park (2006) isimli romanında anlattı̆̆ı, Londra banliyösünde yaşayan ev kadınlarının gündelik hayat pratiklerini analiz ederek, onların direniş ve özgürleşme imkânını çözümleyecektir. Araştırmada, Henri Lefebvre'nin diyalektik bir şekilde teorize ettiği, baskı ve özgürleşme potansiyelini içinde barındıran gündelik hayat kavramından faydalanılacaktır. Bahsi geçen roman analizinde, gündelik hayatın ev kadınları için yarattığı gizil güç keşfedildiğinde, ev işlerinin kadın öznesini dönüştürme ve baskı altına almadaki önemi ortaya çıkacaktır. Dolayısıyla Michel de Certeau'nun gündelik hayatı direniş alanı olarak kutsaması, Arlington Park (2006) isimli romandaki ev kadınlarının başkaldırıcı eylemlerini analiz etmede kullanılacaktır. Bu çalışma, ev kadınlarının gündelik hayat pratiklerini gerçekleştirirken özgürleşme ve direniş gösterme olanağını inceleyerek, gündelik hayatı uzlaştırıcı bir kavram olarak sunacaktır. Sonuç olarak, ev kadınlarının direniş biçimlerinin gündelik hayatlarında oluşturduğu özgürleşme yolları Arlington Park (2006) adlı roman ele alınarak analiz edilecektir.

Anahtar kelimeler: Gündelik hayat, ev kadınları, Arlington Park, ev işi

\section{Introduction: 'Everyday' as a Concept}

This paper will focus on the emancipatory and oppressive qualities of the everyday notion by analyzing the contemporary novel Arlington Park (2006). The fact that the novel narrates everyday practices of the housewives living in London's suburb makes it worthy of analysis mainly because the events take place in 24 hours. This one-day novel helps to scrutinize the hidden unfamiliar within the familiar everyday. In other words, how female protagonists choose to spend their days, what they refuse to do or willingly accept in their everyday practices are shown within a twist. Everyday practices of the subjects are narrated within that specific time period; therefore, it is possible to see the routine and the repetitive actions of the housewives in addition to the resistance they show. The twist and the hidden unfamiliar are in a reciprocal relationship with the notion of resistance. Therefore, the primary purpose of this paper is to show the dialectical nature of everyday by paying close attention to the resistance that housewives can build. It proposes the idea of liberation by a simple act of resistance within everyday life practices of the female subjects. Therefore, it is imperative to understand what everyday notion holds, how it can be oppressive and liberative for its actors, how it can create a space of reaction to oppression, and how it can be a place for alienation. That is to say, alienation can be explained as a process of dehumanization. In this framework, housewives who are alienated within their everyday life can experience disalienation with their everyday resistance tactics. To put it differently, they can be emancipated subjects by discovering the potential of everyday life and the resistance it entails. The following part will give the historical outline of the everyday notion to reveal its powerful role in analyzing the domestic labor of housewives.

Everyday life retains its canon saturated with cultural studies, postmodernism, feminism, and media studies (Gardiner, 2000: 2). The fact that it can be analyzed within various studies has posited the notion with interest, especially after the 1970s. Before the 1970s, everyday life was characterized by routine, mundane, and repetition; however, with the help of everyday life studies, the notion has been conceptualized in a more contested domain. All the same, the sheer ambiguity of the term makes the 
addressing of everyday life difficult. However, this ambiguity, familiarity, and common sensical feature of the notion postulates it worthy of analysis as a focus of social research (Bennet, 2005: 10).

Everyday life has become a research site because it accommodates insights into all reasonable human practices, structures, thought patterns, and meaning-making systems. By analyzing everyday practices, it is possible to understand how people live their lives, how they form their cultures, how they are exploited and how they resist the oppressive structures. Though everyday life practices were regarded as repetitive, mundane, habitual, and residual before everyday life studies embellished the notion with creativity, they are now conceptualized to understand how societies and individual actors operate. In this sense, it is possible to say that everyday is heterogeneous and contested (Bennet, 2005: 3); thus, can offer a diverse range of realities for a variety of subjects.

During the early $19^{\text {th }}$ century, social scientific parlance situated the notion of everyday in a more structuralist approach5, suggesting that the structural forces "took no account of the individual's capacity for agency" (Bennet, 2005: 11). This meant that the everyday life practices of the individuals were cast aside. Collective knowledge existed independently of the individuals since social order entailed consensus. Therefore, human subjects' everyday practices were not taken into consideration. However, during the late $19^{\text {th }}$ century, industrialization and urbanization put the social actors into focus and required an analysis of social interactions and everyday life practices. In addition to that, under the thumb of German hermeneutic tradition, the notion of everyday and the human subjects were put into focus. For example, social theorists like Alfred Schütz, Edmund Husserl, and Max Weber conceived the individual subjects as active agents. In other words, being active agents means that individuals can create their own meanings and be driven by them. Thus, their everyday life practices gained more importance. To put it differently, individuals can construct meanings in everyday life, and their practices can accentuate their agencies because how they interact as subjects are extended towards their social experiences. Indeed, at this point, the notion of everyday came to be seen as a mediator between the individual and the social system. Thus, for instance, to examine social structures, Weber looked for the creativity and the understanding of the social actors. He believed that the actual manifestation of the social relations of capitalism can be traced down to the social agents and the ways they look to enunciate themselves (Bennet, 2005: 2). In this sense, it is possible to say that individual experiences shape our world, and those experiences constitute the core of everyday life. Everyday has the power to oppress and emancipate individuals since it is a sphere of power relations as well. All the same, everyday life can be exploited and manipulated as it can be a space of domination for the individual actors. Therefore, the dialectical sphere of the notion can be discovered in its potential to dominate and liberate the individuals.

To elaborate further, for French Marxist philosopher Henri Lefebvre, this characteristic of the notion exhibits the dialectical nature of everyday. His theorization revolves around the notion's liberative and oppressive qualities. To explore everyday, Lefebvre focuses on the concepts such as alienation, disalienation, modernity, and capitalism. This leads Lefebvre to analyze the signs in everyday life only to discover the struggle that takes place in it. The struggle lies in the lived experience of the notion in a dialectical way which proposes both the alienation of the subjects under the conditions of modernity and a state of disalienation at the same time. In this framework, it is possible to say that everyday stands as

Emile Durkheim can be regarded as one of the defenders of structuralist theory. He believed in the passivity of the individuals in order to preserve the favor of the totality. In this sense, individuals subordinated themselves to the community (Zeitlin, 1968: 257). 
a critique of oppression and alienation because it also offers ways to subversion and transformation due to its dialectical nature (Sheringham, 2006: 12).

In Michel de Certeau's view, everyday is filled with opportunities for resistance and subversive practices that can remind the creative potential of the notion. In this sense, everyday witnesses oppression, liberation, agency, and domination in addition to the sphere of resistance. De Certeau inquires everyday as a space of resistance where subjects can create tactics against the grid of power. By building a new form of ordinariness embedded in everyday life practices, human subjects can reach authenticity and transformation.

These tactical subversive actions that can be observed within everyday life practices are analyzed by elaborating upon the housewives' mundane and repetitive activities in the novel Arlington Park (2006). Their everyday domestic tasks are not seen as residual because of the power everyday holds; thus, they can forge themselves an identity within the resistance they can build as active agents. The critiques of Lefebvre and de Certeau have taken the familiarity of the notion to situate it against the control imposed by the social system; therefore, both critics argue and stand for the revolutionary potential of everyday life practices.

Following the previous introduction to everyday life studies, this paper will now conceptualize the notion of everyday with the help of Henri Lefebvre and Michel de Certeau. The dialectical power of the everyday will be explained via Lefebvre's theorization and the resistance it entails will be taken into consideration with de Certeau's conceptualization. In this sense, it will be possible to analyze the everyday life practices of the housewives in Arlington Park (2006) because Lefebvre's and de Certeau's theorizations exhibit the transformative power of the notion. Hence, after giving the historical outline and the theoretical framework of the notion, the present study will discuss the one-day novel Arlington Park (2006) to show the hidden creative power in everyday practices of the housewives in addition to the resistance they bring about.

\section{Theorization: Henri Lefebvre and Michel de Certeau on Everyday Life}

For Henri Lefebvre, everyday life "is profoundly related to all activities, and encompasses them with all their differences" (1991: 27). Therefore, it can be said that everyday is a concept of lived experience and infused with all forms of power relations. For him, the present world is governed by the administrative forces, bureaucracy, capitalism, and consumerism. Thus, modernity penetrates into the fabric of everyday life. This creates a form of alienation because modernity can exploit everyday practices. Cultural industry and rupturing of modernist conceptions shape identities in the sense their everyday life practices are organized and dominated. Moreover, advertising and consumerist culture lead to what Lefebvre defines as the "bureaucratic society of consumed consumption" (Lefebvre, 1984: 68). This forms a platform to control the everyday life practices of the individual actors. People cannot decide on what to consume or desire because, in the capitalist society, mass media is used to manipulate people into buying products; thus, regulating their consumption habits. Therefore, the sphere of everyday life may become problematic in the modern era (Chaney, 2002: 16) simply because everyday as a notion becomes a space plagued by capitalist modernity.

All the same, for Lefebvre, everyday modernity can also come up as a critique of the notion itself. In this sense, the study of everyday life as a cultural theory lies in its ability to make the familiar unfamiliar. To be more apparent, the repetitive, mundane, and taken-for-granted actions revolving around the routine 
of everyday practices can be an area of struggle both politically and socially. Thus, everyday holds more than what consumerist culture and bureaucratic structures allow. Lefebvre defines this as the dialectic of everyday. Therefore, the dialectical power embedded in everyday practices holds the opportunity of transformation. In Hegelian terms, the dialectical conflict and potential in everyday propose that it can be exploited and accentuate a form of alienation under the conditions of modernity and its direct opposite, which can propose a form of consciousness that can lead to disalienation. Lefebvre theorizes this process of liberation in everyday life practices because the opportunities embedded in them can spare resistance and objection. Lefebvre argues that "moments" in everyday life can be revolutionary and transformative (Elden, 2004: 172). Against the fragmentation and commodification of modernity, he prioritizes "moments" because they can help us to observe the everyday world.

What makes his dialectical conceptualization significant is the idea that everyday can come up as a critique of its own exploitation. It can be presented as a space for resistance. Lefebvre argues for a definition of everyday that is both oppressive and liberative. Therefore, it facilitates further theorization of the notion by de Certeau, who believes in the hidden power of the everyday. The field of everyday can be a place of pluralized power that can culturally produce identities. Technology, with the help of capitalism and modernity, has invaded everywhere. This has empowered the culture of consumption to present needs and desires for the everyday person. The culture industry has capacitated culture to become a commodity that can be bought and sold. All the same, this mechanism has enabled individuals to develop tactics against the structures that control them.

De Certeau (1980) defines tactics as mechanisms that can stand against the apparatuses embedded within everyday practices. These tactics help subjects to discover their potentials, authenticities because they are given a chance to discover themselves. Everyday practices are instrumentalized by modernity and capitalism, leading to the internalization of mass culture. However, tactics developed by individuals within their everyday life practices can liberate them. For de Certeau, a considerable number of everyday practices are tactical by their nature (1980: 9) such as the domestic tasks of the housewives in Arlington Park (2006). For example, cleaning, cooking, washing the dishes, and ironing are narrated as everyday practices for the housewives. Those activities can also be seen as an extension of imprisonment and oppression imposed by the patriarchy. Therefore, the routine and the repetitive roles of the housewives may posit them as passive recipients. However, with de Certeau's conceptualization, it is argued that individual actors have the power to resist the hegemony and the structures that can control them. This resistance lies within the mundane and repetitive acts of everyday practices such as reading and talking. Thus, the cultural industry and the theme of alienation as an extension of it can be resisted. The individual actor is not a passive agent or a victim of the superstructure, yet a social actor. Therefore, micro and little acts of everyday life can create a potential for transformation.

Everyday is both "known and unknown" (Highmore, 2002: 16); thus, its being dialectical holds various meanings embedded in itself. De Certeau's analysis aims to understand how power is integrated into the sphere of everyday and helps to look for ways of resistance. In addition, how the tactics that are developed by the individuals can subvert the power structures composes the core of de Certeau's theorization of everyday. Though Lefebvre proposed the dialectical power and creativity of the notion, he believed in the possibility of revolution and emancipation on a macro level. All the same, he defended the idea that revolution lies only within the creative space that everyday life proposes. In his own words: "A revolution cannot just change the political personnel or institutions; it must change la vie quotidienne, which has already been literally colonized by capitalism" (1988: 79-80). For him, the Soviet Revolution was not successful because it failed to transform the notion of everyday or rather it was not 
able to help the creative potential of individuals to be released within their everyday life practices (Highmore, 2002: 131). What he means by the revolutionary transformation of the notion is "overcoming and obliteration of the everydayness of everyday life" (Highmore, 2002: 144). All the same, developing the notion in its dialectical characteristics, Lefebvre situates the concept of everyday within capitalist logic. He focuses on the alienation and disalienation concepts which can be achieved via everyday practices so that the notion can create political outcomes. However, for de Certeau "nothing could be more damaging to the study of everyday life than to greet it with a prescriptive 'political' assessment" (Highmore, 2002: 150). He believes in the possibility of a revolution on an individual level because social actors can develop tactics (Highmore, 2002: 163). That is to say, everyday is a sphere where individuals practice and perceive power; thus, practices of resistance can be exercised within its dynamism as well. Its dialectical and creative quality embellishes social actors with personal tactics so that everyday resistance can be built.

As the main focus of the present paper is to evaluate the everyday resistance of the housewives in Arlington Park (2006) embedded within their everyday practices, Lefebvre's and de Certeau's theorization of the notion profoundly helps with grasping the dynamics that everyday possesses.

\section{Discourse Analysis: Resistance and Everyday Experience of the Housewives in Arlington Park (2006)}

This paper bases the analysis of everyday life and its potential in connection with the everyday experiences of the housewives in the contemporary literary work Arlington Park ${ }^{6}$.(2006) written by Rachel Cusk. The novel narrates the everyday experiences of the housewives who live in a suburb called Arlington Park near London. Arlington Park is the perfect example of a suburb with its shopping mall, butchers, hairdressers and kindergartens. It is narrated as a place that can present everything that a housewife needs in her everyday life practices as a spatial structure. The physical setting of the suburb entails a visit to the grocery store, a daily conversation with the butcher, a visit to the shopping mall to socialize and drink coffee; therefore, through the whole narrative, everyday life practices of the housewives can be traced meticulously. It is possible to read the interrelated stories of housewives and their everyday experiences; thus, the dialectical nature of the notion, in addition to the possibility of resistance, can be traced within the novel. In this sense, the theorization of Lefebvre and de Certeau's conceptualization of the notion are benefitted from in order to discuss the everyday practices and resistance of the main female protagonists.

To be more specific, the novel takes place in a day. Namely, it starts with a rainy day in the suburb and ends at a dinner table. It portrays the everyday life practices of four different families and mainly focuses on the lives of the female protagonists. Characters in the novel embody different fragmentations of subjecthood even though their everyday life practices are similar to each other. They each deal with their own problems in a unique way and their handling of everyday life practices show the dialectical nature of the notion. In other words, their everyday life practices oppress and liberate them at the same time. To explain further, the first female protagonist the novel introduces is named Juliet Randall. We read her everyday practices as a thirty-six-year-old woman. She is represented as a woman to resist her pregiven roles as a housewife and a mother by developing tactics within her everyday life practices. The second protagonist who is introduced after Juliett Randall is Maisie Carrington. She is thirty-eight years old and feels unstable in her life. Similarly, she describes her role as a housewife and a mother as "imprisoned for life" (Cusk, 2006: 173) and looks for ways to emancipate herself from the heavy burden

This novel is seen as the rewriting of Virginia Woolf's Mrs. Dalloway (1923). 
of her everyday life practices. Then, the story of Solly Kerr-Leigh is introduced. She is a pregnant housewife waiting for her fourth child, and she reflects upon her life through the novel to discover her lost femininity. Even though we witness the lives and experiences of those women collaboratively through the whole narrative, Christine Lanham and her way of transforming her everyday practices are narrated at the end. She prepares a dinner party for Randall, Carrington and Spooner families, and her invitation of other families to her dinner party provides a close analysis of the dynamism they hold in the suburb.

The fact that women go on and about their everyday routines within a day makes this novel worthy of analysis because it can simply accentuate the routine, the repetition, and the resistance embedded in everyday practices at the same time. Female protagonists visit the supermarket, go to a coffee shop, take their children to school in addition to their domestic tasks at home. However, the main focus is on the value of their domestic labor and how they can resist and subvert their pre-given roles as bored and straightforward housewives whose only job is to clean the house. Throughout the narrative, housewives are given agency and authenticity because of their ability to develop tactics against their pre-given roles. These tactics are hidden in their everyday practices. In this framework, Arlington Park (2006) narrates the microcosms of individual experiences of the housewives; therefore, everyday life practices become a matter of discussion as they have the power to oppress and liberate the female subjects in the novel.

As mentioned, one of these female subjects is named Maisie Carrington in the novel. She is a mother of two children, and her everyday routine consists of taking care of the children and carrying out the domestic tasks within her household. Her husband expects her to keep a clean home and put hot food on the table because these are narrated to be the responsibilities of a good wife and a mother. However, feeling repressed and dominated, Maisie questions her life and this questioning is reflected in her everyday practices. She wants more in life than cleaning the house and cooking food for her family; however, she lacks the ways to bring her independence. Therefore, she develops tactics as de Certeau would name to gain her authenticity. For example, in one of the chapters, Maisie's husband, Dom Carrington, arrives home from work and sees the house untidy. The following quote describes their dialogue:

He said:

"What's been happening here?"

The overhead lights were on all around the ground floor. Their hard orange brilliance was reflected in the black uncurtained windows. The rooms-kitchen, sitting room, a room at the front, the cluttered hall where Dom stood enquiringly-had the yellowed appearance of a network of well- lit underground tunnels.

Maisie said, "What do you mean, what's been happening? Nothing's been happening."

The direction of the light made the sitting room look as though it were listing to one side. Big, sagging bookshelves went in uneven stripes across one wall. The empty black mouth of the fireplace stood open in a frozen protest. In front of it an Indian rug lay twisted in an attitude of torment. Discarded toys made patterns over the floor like the patterns of land masses on a globe, halting where they met the obstacle of the sprawling sofa indented with craters where people had sat and eventually got up again. Maisie felt rather than saw the reality of the kitchen, whose full extent was shielded by the halfshut door. It receded from her in a long, soiled, debrisstrewn segment (Cusk, 2006: 134).

As the novel takes place in a day, seeing the house untidy in that specific one day exhibits the power of repetitiveness embedded in everyday life. An act of not tidying the house can be seen as a resistance and a subversion of the roles prescribed within housewifery. Arlington Park (2006) shows the extraordinary within familiarity on this specific day. By looking at the mentioned dialogue, the everyday life practices 
of the housewives and the tactics they build as resistance can be analyzed. Dom cannot make sense of the untidy house and questions the state of his wife by asking, "What's been happening here?" (Cusk, 2006: 134). Maisie responds in the following lines: "What do you mean, what's been happening? Nothing's been happening” (Cusk, 2006: 134). Even though she is perfectly aware of the problem, she behaves like nothing is wrong. Her inert tactic to protect her individuality is shown here because she gives herself a choice not to clean the house. De Certeau defines some tactics as inert tactics because they do not correspond to the subversive cleverness and imagination. Tactics have the power to turn the structures and expectations upside down, and what Maisie did by simply refusing to do the domestic task as a housewife creates a space for her individuality, namely emancipation and disalienation. Living in the suburb with two children creates a burden and a structure for her to be the perfect wife and a mother. However, she feels at ease when she sees a pack of dirty clothes in front of her. In addition to de Certeau, who would call her refusal to clean the house as a tactic, Lefebvre would name her reaction as a "moment" (Lefebvre, 2002) because only within that moment, she questions her identity as a woman and chooses not to abide by the rules chosen for her simply by refusing to do a domestic task in her everyday life.

The same act of resistance can be seen in Christine Lanham's everyday practices in Arlington Park (2006). She is a close friend of Maisie, and at the end of the novel, we read about her dinner party because she has invited everyone in her neighborhood for dinner. The dinner table represents her responsibilities as a mother and a wife because her cooking skills accentuate her suitability for the housewifery. However, during the dinner, we read her interior monologue in the form of a stream of consciousness. She keeps questioning her role as a housewife and keeps saying to herself that "she wanted to be living-living!" (Cusk, 2006: 180). She does not want to pass the butter or prepare the dinner table but to live her life as she pleases. The fact that we read her mind as an interior monologue rather than explicit acts of behavior compared to Maisie exhibits the seriousness of her imprisonment. Even though she cannot build a pattern of behavior against the structures, it is possible to read her tactics in their "inert' and stubborn guise" (Highmore, 2002: 161). Nonetheless, it is imperative to state here that while Christine was seeing her dinner guests off at the end of the novel, she rolled the carpet in her living room and started dancing. This act of dancing was not understood by anyone in the living room as there was no music. The following quote narrates the scene:

\footnotetext{
"You're not leaving, are you?" said Christine. "Not you two! I was just about to start rolling back the rug-I was getting the music on and dancing."
}

There was no music, but she danced anyway. She danced in front of them. She raised her arms above her head and snapped her fingers and moved her hips from side to side (Cusk, 2006: 185).

Everyone was quite shocked and could not make sense of this behavior. Christine was perfectly aware of her situation as a housewife, wife, and mother. She could not run away from her everyday life practices. However, this act of dancing at the end of the novel can be evaluated as an act of liberation because she developed her way of dancing without music. Hence, we can read her monologue through the dinner as a reflection of her questioning. Moreover, her dance at the end of the novel can be evaluated as an act of resistance because it shows her ability to control her everyday life practices. By creating an area for herself at the end of the dinner, she was able to step outside of the expectations that were created for her as a housewife. As a female character who hosted a dinner party, Christine questioned her role and identity through the whole dinner. Therefore, her act of rolling the carpet aside and dancing without music under the shocked expressions of her guests highlights her resistance tactic to situate her agency. Therefore, the fact that she was able to express herself within the micro felid reality of everyday life shows the dynamic potential of the notion. As a housewife, her everyday life was controlled by 
consumerism, capitalism, modernism, and patriarchy; however, all the same, as an active individual who can develop tactics to situate human agency, she was able to form a reaction and resistance. Nevertheless, the novel ends with the following lines: "She did her dance again, snapping her fingers. Joe looked at her with bottomless eyes. 'Come here,' he said” (Cusk, 2006: 186). Joe is Christine's husband, and as described, he holds her and stops her dance to inaudible music. Though her dancing can be interpreted as an act of resistance and individuality, the fact that her husband interrupts this "moment" exhibits the dialectical nature of the everyday notion. She is free and oppressed at the same time.

In this framework, it is possible to say that female characters looked for ways of emancipation within their everyday practices such as cleaning the house and preparing the dinner table. At those specific "moments" narrated in Arlington Park (2006) as a one-day novel, they were able to forge themselves new identities. Everyday notion and its repetitive practices posit the concept both as dominative and liberative. Therefore, individuals are given autonomy to shape their experiences within the creative and dialectical characteristics of the notion. In this sense, everyday life studies, with its two essential sociologists such as Lefebvre and de Certeau, enable an analysis of a locus where actors construct tactics against the grid of externally imposed power relations.

\section{Conclusion}

In Arlington Park (2006), everyday routine and the domestic tasks of the housewives are narrated in the suburb Arlington Park. In this framework, this paper focused on the possibility of emancipation embedded in the everyday life practices of the female protagonists in the novel. By focusing on the everyday resistance tactics of the housewives, this paper evaluated the power of resistance that can be built within the everyday life practices. In order to highlight this, everyday domestic labor and the resistance against the domestic tasks were analyzed. Resistance built by the female characters such as Maisie Carrington and Christine Lanham were elaborated upon in a detailed manner. For example, Maisie's narrative revolved around the sphere of domesticity because her everyday practices as a housewife required her to keep a clean house at all times. By her refusal to tidy the house, it was possible to see the dynamism between her and her husband, the patriarch of the house. Christine, on the other hand, was not able to act or say anything implicitly. She was not as verbal and active as Maisie. However, her disguised tactic to show everyone that she has control over her life at the end of the novel by dancing without music and her interior monologue shows both the emancipatory and liberating quality of the everyday notion. The resistance disguised within the phenomenon of everyday concedes and then proceeds the dialectical power it beholds.

All in all, these female protagonists can resist the structures unconsciously and consciously, visibly and secretly. They are able to forge themselves an identity by refusing to do the household chores or imagining not to pass the butter or cook dinner at a dinner table. They are narrated as the active individual actors of their everyday life practices. All the same, it is possible to observe the oppressive quality of the notion simply because the novel is set in a day, and we read the extraordinary acts of resistance against the grid. The next day would consist of cleaning the house and not dancing at the end of the dinner party. Even though the routine would continue for the housewives and entrap them within their everyday life practices with the help of the structures of modernity, one would ask: "Would it be the same now that individual actors have questioned their roles and resisted against them?" and this resistance lied in everyday practices. This basically shows the potential, and the power everyday notion possesses. Therefore, it is possible to say that we have been able to discover the dialectical nature of 
everyday and the resistance it holds within the practices of the female protagonists in Arlington Park (2006).

\section{Bibliography}

Bennet, A. (2005). Culture and Everyday Life. Sage Publications Ltd.

Chaney, D. (2002). Cultural Change and Everyday Life. Palgrave.

Cusk, R. (2006). Arlington Park. Farrar, Straus and Giroux.

De Certeau, M. (1980). Practice of Everyday Life. University of California Press.

Elden, S. (2004). Understanding Henri Lefebvre. Continuum.

Gardiner, M. E. (2000). Critiques of Everyday Life: An Introduction. Routledge.

Highmore, B. (2002). Everyday Life and Cultural Theory: An Introduction. Routledge.

Lefebvre, H. (1984). Everyday Life in the Modern World. Transaction Publishers.

Lefebvre, H. (1991). Critique of Everyday Life: Volume I, Introduction J. Moore (trans.), Verso.

Lefebvre, H. (1988). Marxism and the Interpretation of Culture. "Towards a Leftist Cultural Politics: Remarks Occasioned by the Centenary of Marx's Death" University of Illinois Press.

Lefebvre, H. (2002). Critique of Everyday Life, Volume 2. London: Verso.

Sheringham, M. (2006) Everyday Life: Theories and Practices from Surrealism to the Present. Oxford University Press.

Zeitlin, I. (1968). Ideology and Development of Sociological Theory. Englewood Cliffs, New Jersey: Prentice-Hall. 